\title{
Adaptation of agriculture to climate change in semi-arid Borena, Ethiopia
}

\author{
Stanley Karanja Ng'ang'a ${ }^{1,2,3} \cdot$ Mark T. Van Wijk ${ }^{1} \cdot$ Mariana C. Rufino $^{4} \cdot$ \\ Ken E. Giller ${ }^{3}$
}

Received: 22 September 2014/ Accepted: 25 February 2016/Published online: 1 April 2016

(C) The Author(s) 2016. This article is published with open access at Springerlink.com

\begin{abstract}
Livestock production is very risky due to climate variability in semi-arid Sub-Saharan Africa. Using data collected from 400 households in the Borena zone of the Oromia Region, we explored what drives adoption of agricultural practices that can decrease the vulnerability of agro-pastoralists to climate change. Households with more adaptive capacity adopted a larger number of practices. The households' adaptive capacity was stronger when the quality of local institutions was high. However, adaptive capacity had less explanatory power in explaining adoption of adaptation options than household socio-economic
\end{abstract}

Editor: Christopher Reyer.

Electronic supplementary material The online version of this article (doi:10.1007/s10113-016-0940-4) contains supplementary material, which is available to authorized users.

Stanley Karanja Ng'ang'a

stanley.nganga@wur.nl; s.karanja@cgiar.org

Mark T. Van Wijk

M.VanWijk@cgiar.org

Mariana C. Rufino

M.Rufino@cgiar.org

Ken E. Giller

ken.giller@wur.nl

1 International Livestock Research Institute (ILRI), P.O. Box 30709, Nairobi 00100, Kenya

2 Development Economics Group, Wageningen University (WUR), P.O. Box 430, 6706 KN Wageningen, The Netherlands

3 Plant Production Systems (PPS), Department of Plant Sciences, Wageningen University (WUR), P.O. Box 430, 6700 AK Wageningen, The Netherlands

4 Centre for International Forestry Research (CIFOR), P.O. Box 30677, 00100 Nairobi, Kenya characteristics, suggesting that aggregating information into one indicator of adaptive capacity for site-specific studies may not help to explain the adoption behaviour of households. Strong local institutions lead to changes in key household-level characteristics (like membership to community groups, years lived in a village, access to credit, financial savings and crop income) which positively affect adoption of agricultural practices. In addition, better local institutions were also positively related to adoption of livestock-related adaptation practices. Poor access to a tarmac road was positively related to intensification and diversification of crop production, whereas it was negatively related to the intensification of livestock production, an important activity for generating cash in the region. Our findings suggest that better local institutions lead to changes in household characteristics, which positively affect adoption of adaptation practices, suggesting that policies should aim to strengthen local institutions.

Keywords Adoption - Adaptation - Agro-pastoralists . Borena $\cdot$ Adaptive capacity $\cdot$ Institutions

\section{Introduction}

Livestock and crop production risks due to climate variability are widespread in the arid and semi-arid lands (ASALs) of sub-Saharan Africa. In such dry regions of East Africa, most agricultural households are pastoralists or agro-pastoralists who struggle to cope with current climate variability (cf. Cooper et al. 2008). Climate change will most likely exacerbate this situation. Although rainfall is likely to decrease only in a few places in East Africa, the anticipated increase in rainfall will not increase agricultural productivity due to unfavourable timing and distribution of 
precipitation (Thornton et al. 2010). Thus, the livelihoods of many low-income households are likely to suffer from declining food production (Jones and Thornton 2009). Adaptation is an urgent priority for farm households to reduce the negative effects of climate change, and effective policies are needed to support farm households to adapt (Kurukulasuriya et al. 2006).

The ability of pastoral and agro-pastoral households to adapt is constrained by many factors including land degradation, limited education, poor access to financial resources and markets to diversify their livelihoods, gender inequalities and marginalization (Njuki and Sanginga 2013). How the negative effects associated with climate change can be reduced depends on a favourable institutional environment to alleviate these constraints, thereby increasing the capacity of farm households to adopt effective adaptation practices (Di Falco et al. 2011; Jones et al. 2010; Thornton et al. 2007). Many householders in ASALs are unable to test new adaptation practices such as new crop varieties, drought-tolerant livestock and reducing soil degradation due to their low capacity to invest, lack of inputs and access to information (Bryan et al. 2013). Adaptive capacity as used in this paper refers to 'the ability of the (human) system to adjust to climate change (including climate variability and extremes), to moderate potential damages, to take advantage of opportunities, or to cope with the consequences' (Field et al. 2012). The implication is that capacity to adapt varies among households and that the forces that influence the ability of the system to adapt are the drivers or determinants of adaptive capacity (Adger 2003, 2006). Low adaptive capacity is mostly attributed to a deteriorating ecological base, widespread poverty, high dependence on natural resources and poor access to these resources (Hulme et al. 2001; Intergovernmental Panel on Climate Change (IPCC) 2013; Kelly and Adger 2000; Smit and Pilifosova 2001).

We define vulnerability as the 'the level of exposure and defencelessness against risks' (Dercon 2006). In ASALs of East Africa, four main risk categories have been identified: climate variability, disease outbreaks, market imperfections and risks of policy shocks (Ouma et al. 2011). Of these, risks associated with climate extremes, primarily drought with occasional flooding, are the most severe and constraining for pastoralists or agro-pastoralists (Ouma et al. 2011). Scoones (2009) and Babulo et al. (2009) suggest that the ability of households to pursue different livelihood strategies and thereby adapt to climate change depends on ownership of assets.

In Ethiopia, research suggests that adoption of adaptation practices increases food production per unit land area and households net income (Di Falco et al. 2011). Adaptation can be supported by policy makers through provision of credit, information, inputs and extension (Hisali et al.
2011; Tambo and Abdoulaye 2012). Below et al. (2010) showed that improving rural transportation, infrastructure, weather forecasts, investment in public health care and policies that improve local governance and coordinate donor activities can increase adaptive capacity for African farmers. Recent literature on farmers' behaviour in relation to climate change and variability shows that age, education, household size and income are important determinants of adaptation (Bryan et al. 2013; Deressa et al. 2009; Hisali et al. 2011). The importance of institutions and entitlements (such as access to common property resources) enabling households to adapt has received less attention (Jones et al. 2010). Despite the large body of literature on adaptation, and the increasing importance of promotion of agricultural technologies for climate adaptation, little empirical research has explored the link between adoption of agricultural adaptation practices and determinants of adaptive capacity. A better understanding of this link is needed to inform policies that aim to promote adaptation to climate change in the ASALs.

We focus on autonomous adaptation and investigated the relationship between adoption of agricultural options that can decrease the vulnerability to climate change and adaptive capacity among pastoralists in Borena, Ethiopia. The Borena region is one of the 13 administrative zones within Ethiopia's Oromia state. The region is semi-arid savannah, marked by flood plains vegetated predominantly with grass and bush land and frequently exposed to droughts. Borena was chosen as a case study because it is typical for the agro-pastoral areas in the horn of Africa where biophysical constraints and social rules and institutions may limit the space for adaptation. We hypothesized that: (1) the quality of local institutions is a key driver of adaptation at household level influencing overall adoption by governing access to resources, and (2) adoption of specific adaptation options is determined by household assets, farming experience, financial resources, household age and gender, and membership to community groups.

\section{Methods}

\section{Study area}

This study was conducted in southern Ethiopia in the Borena zone of Oromia regional state in the districts of Yabello and Arero which lies between $4^{\circ} 41^{\prime}-5^{\circ} 03^{\prime} \mathrm{N}$ and $38^{\circ} 17^{\prime}-38^{\circ} 33^{\prime} \mathrm{E}$. The zone covers an area of approximately $95,000 \mathrm{~km}^{2}$ with an overall population density of six inhabitants per $\mathrm{km}^{2}$. The climate is hot and dry, with mean monthly temperature ranging between $15{ }^{\circ} \mathrm{C}$ (July) and $24{ }^{\circ} \mathrm{C}$ (January) with little variation between seasons. The area is semi-arid with highly variable rainfall ranging 
between 500 and $900 \mathrm{~mm}$ per annum. The rainfall is bimodally distributed with long rain occurring between March and June, and short rains between August and October (Solomon and Coppock 2004). The elevation ranges between $1000 \mathrm{~m}$ above sea level on the plains to $1500 \mathrm{~m}$ in the highlands (Solomon et al. 2007).

The predominant form of livelihood is semi-nomadic pastoralism, but current estimates indicate that less than $15 \%$ of households in Borena rely on livestock production alone. The majority of households rely on both arable farming and livestock production (Angassa and Oba 2008). Rain-fed cropping of maize, sorghum, teff and barley is the common practice. Fences are often erected to protect crops from damage by livestock and wildlife. Cash for buying maize - the main staple food-is derived from the sale of livestock and livestock products. The common livestock species are goat, sheep and cattle, with an increasing population of camels. Areas with good quality pastures are reserved as enclosures for use in dry periods by calves and to a lesser extent milking cows. Croplands, pastures and watering points are communally owned, and access to them is regulated through local institutions (Solomon et al. 2007).

The behaviour of households in Borena zone is regulated by local institutions, which are part of the Borenawide (Appendix 1), generation' ${ }^{1}$ grading 'Gada' system (Watson 2003). In the Gada system, rights to water use are organized and regulated by the well owners locally known as 'Abba hirega'. The management of pasture including migration of livestock is under a territorial unit leader locally known as 'Abba dheeda'. The village leader or 'Abba olla' is the person who started a village and is in charge of resolving conflicts. Several villages make up an 'olla'. The 'olla' leader locally known as 'Abba eela' is in charge of organization of all villages encompassed in their 'olla' as defined by the Gada system. Conflicts relating to land, water, pastures and social issues in villages are mediated by the local judiciary known as 'Ayyu'.

\section{Data}

Data were collected between August and September 2013, interviewing 400 households from 40 villages randomly selected from six pastoral associations (PAs), the administrative level encompassing several villages: Gada, Hallona, Dambala-Saden, Dikale, Harboro and Abunu. These PAs constitute Yabello and Allona woredas. Thus, data were collected in the two woredas (i.e. Yabello and Allona) that were selected as representative of climate, soil, geography and household socio-economic conditions

\footnotetext{
${ }^{1}$ One generation rules for 8 years and then succeeded by the next one.
}

encountered in northern Borena. From the two woredas, six PAs were randomly selected from a PAs list. Then using a list of village names in each of the PA that had been developed with the help of key persons, 40 villages (locally referred to as olla) were randomly selected. A key person was somebody with good insight about the area such as village boundaries and on social dynamics. Finally, using household lists for each of the selected olla developed with the help of village leader, ten households were randomly selected so that the total sample size was 400 households. Data were collected with the help of six local enumerators who were trained for 5 days in both English and the Oromiffa language spoken by the largest ethnic group in Borena to ensure a good understanding of the research questions. To maintain consistency during the interviews, each enumerator was provided with an Oromiffa version of the questionnaire to serve as a reference point throughout the survey period, although data were recorded in English. We collected information on a range of households' characteristics to estimate human, natural, financial, physical and social capital as summarized in Table A1. In this paper, households' socio-economic characteristics are considered as availability of resources for household and access to them (i.e. they constitute five capitals).

\section{Human capital}

Education is an important measure of human capital due to its importance to secure employment and skills for managing scarce resources (Saenz and Morales 2005). We measure education as the number of years spent in school. Large household size provides labour, thus enabling households to accomplish various tasks in a short time (Croppenstedt et al. 2003). To estimate household size, the age and gender of household members who share shelter, production and consumption activities (i.e. 'eat from the same food pot') were recorded and converted into adult equivalents (AE) following the method by Martin (1985). Then, we compute a human dependence ratio (HDR) as the proportion of households' members aged below 15 and above 65 years of age to AE. Experience increases the ability to adopt adaptation measures (Nhemachena and Hassan 2007). In this study, experience was estimated by the number of years the households head practiced farming. To estimate 'hired labour', we assigned a dummy variable 1 to households that hired labour during the last 12 months and zero otherwise.

\section{Natural capital}

Natural capital was estimated as access to land, water and wildlife products. Arable land was measured using a geographical positioning system (GPS). To assess 'natural 
resources constraint', we asked two questions: (1) whether households pay to access natural resources (i.e. water, forest/shrub land and pastures) and assigned a value of 1 if the answer was affirmative and 0 if otherwise, and (2) whether there are rules ${ }^{2}$ regulating access and use of these resources (Table A2) and assigned a value of 1 if the answer was affirmative and 0 if otherwise. These values were summed and averaged to constitute 'the natural resource constraint'. We used equal weighing as we lacked field data to indicate preferential weights. Our standardized scale showed a Cronbach's alpha reliability of 0.507 . Natural resource constraint was included because low livestock prices after drought may induce households to pursue alternative coping strategies such as charcoal making (Abule et al. 2005). A larger value for natural resource constraint would minimize unsustainable use of resources.

\section{Financial capital}

Financial capital represents the financial resources (e.g. credit, saving and income) available to a household (Nawrotzki et al. 2012). Principal components analysis (PCA) was used to identify non-correlated financial resources (Appendix 2) available to households and used as proxies for financial capital. Access to credit and financial saving were estimated by a dummy variable taking the value of one if the household had used credit and if the households saved money in the last 12 months. Crop and livestock income were obtained by subtracting direct production costs from estimated revenues and selfconsumption.

\section{Physical capital}

An asset index analysis (Bill and Melinda Gates Foundation 2010) was adapted. The asset index for domestic, transport and productive assets was calculated. Each of the assets was assigned a weight $(w)$-as shown in Table A3, which were then adjusted for age (Njuki and Sanginga 2013). The total asset index was then summed for each household (Eq. 1).

Household asset index $=\sum_{g=1}^{G}\left[\sum_{i}^{N}\left(w_{g i} \times a\right)\right]$

where $i=1,2, \ldots N ; g=1,2, \ldots G ; w_{g}=$ weight of the $i$ th item of asset $g ; N$ is the number of assets $g$ owned by a household; $a$ is the age adjustment to the weight; and $G$ is the number of assets owned by a household.

\footnotetext{
${ }^{2}$ Rules represents a 'real' resource constraint in Borena since those who break them are punished (Coppock 1994).
}

\section{Social capital}

We assumed that social capital is characterized by a strong social network and rural reciprocity (Binswanger and McIntire 1987; Bowles and Gintis 2002; Fafchamps and Minten 2001). We use five proxies for social capital: sharing during hard times, ${ }^{3}$ group membership, degree of participation in group meetings and participation in group activities (including donations). To estimate sharing, we asked respondents to rate their degree of sharing among household members, extended kin and fellow village members, where 0 indicated no sharing and 1 indicated sharing. These variables were then averaged so that a value of 1 indicated sharing in all three groups. We asked households whether they were members of any community groups. To those answering affirmatively, we asked how many groups they had joined and their degree of participation in group meetings and activities. Participation in meetings was estimated using a 0-4 (low to high) point scale. We also created a dummy variable to estimate participation in group activities such as elections, campaigns and conflict resolutions. These dummies were then averaged for each household, so that a value of 1 indicated full participation in group activities and 0 indicates no participation.

\section{Local institutions}

We collected data on three dimensions of local institutions following (Acemoglu and Johnson 2005): tenure security, rule of law, governance and accountability (Table A1). We used payment of taxes for cropland and livestock grazing as a proxy for tenure security. To estimate tenure security, we asked households how much tax they had paid for their crop plot(s) and livestock during the last 12 months. These values were then converted into an index. In Borena, land use right to households is accredited by the village leaders in consultation with the PAs. However, payment of taxes to the PAs is a sign of 'de facto' ownership and right to use the land by householders as perceived by the village leaders. Since the olla leader has the right to allocate land to other uses or to other householders, payment of the tax serves as a constraint for land reallocation.

To estimate rule of law, the respondents rated on a fivepoint scale (low to high) the quality of the rule of law as applied by (1) local judiciary ('Ayyu'), (2) the territorial leader ('Abba dheeda'), (3) the well keepers ('Abba hir$e g a ')$, (4) the leader of several villages ('Abba eela') and (5) the village leader ('Abba olla'). The responses were averaged into an index for 'rule of law'. To estimate

\footnotetext{
${ }^{3}$ Our computation of social capital excludes trust, because it was significantly correlated (at $\mathrm{p}<0.001$ ) with sharing during hard times.
} 
governance and accountability, we asked respondents to rate on a five-point scale (low to high) the Ayyu, Abba dheeda, Abba hirega, Abba eela and Abba olla, on: (1) degree to which they involve householders in their decision-making, (2) degree of transparency in their decisionmaking, (3) degree they represent the interest of the householders in the community and (4) degree of transparency in coordinating activities such as food aid and communicating important information from Gada leaders to the householders. These responses were averaged and then converted into the governance and accountability index. In this paper, quality of institutions means the degree to which local institutions are free from poor management and corruption (Voors et al. 2011).

\section{Spatial and information variables}

Market access was estimated by quantifying the distances from each homestead to roads (i.e. tarmac and motorable) and markets (i.e. local, urban and livestock markets) as summarized in Table A1. All distances were measured in kilometres using a GPS by driving those paths. To estimate access to information, we collected information on ownership of mobile phones (dummy variable 1 or 0 ).

\section{Adopted adaptation options}

Data on adopted practices were gathered by posing an open-ended question on whether there were any agricultural practices they had adopted to minimize risks associated with climate variability during the 7 years prior to the field survey. Those who responded 'yes' were asked to list the practices they had adopted (Table 1). The practices analysed in this study should increase the capacity of the farm household to cope with and adapt to climate-related risks, and we call them 'adaptation options'. The listed adaptation options compare well with options for dry lands found in the literature (Bryan et al. 2013; Fratkin 1991; Little et al. 2001; Rufino et al. 2013; Thornton et al. 2007). Before eliciting households' responses on adaptation options, we sought to know what household understood by 'climate change' through a focus group discussions (FGDs). Most households indicated that climate change meant reduction in rainfall, rainfall becoming more erratic, droughts becoming more frequent and more severe and severe reduction in pastures. The changes perceived by the households are associated with current trends in the region (Debela et al. 2015).

Table 1 Percentage of households adopting adaptation practices among households in the last 7-10 years

\begin{tabular}{|c|c|c|}
\hline Acronym & Adopted adaptation practices across household during the last $7-10$ years & $\begin{array}{l}\text { Households }(\%) \text { who had adopted } \\
\text { a particular practice }\end{array}$ \\
\hline \multicolumn{3}{|l|}{ Income diversification } \\
\hline Off-farm job & At least one household member working off farm & 15 \\
\hline Start trade & Started some form of trade/business & 8 \\
\hline \multicolumn{3}{|l|}{ Livestock related } \\
\hline Migration & $\begin{array}{l}\text { Some members migrate with livestock, while others are left to work on } \\
\text { croplands }\end{array}$ & 44 \\
\hline Feed conservation & $\begin{array}{l}\text { Started conserving feed for livestock (e.g. collecting grass at times of } \\
\text { abundance) as hays }\end{array}$ & 48 \\
\hline $\begin{array}{l}\text { Drought-tolerant } \\
\text { animals }\end{array}$ & Introduced drought-tolerant animals such as camel & 31 \\
\hline Hired labour & Started using hired labour to graze the livestock & 8 \\
\hline \multicolumn{3}{|l|}{ Crop related } \\
\hline Use manure as fertilizer & Started applying manure on cropland as fertilizer & 12 \\
\hline Use hybrid seeds & Started using hybrid varieties of seeds & 32 \\
\hline Erosion control & Started putting soil erosion control measures on their croplands, i.e. grass strips & 48 \\
\hline More crop plots & Opened up new crop plots & 72 \\
\hline Intercropped & Started intercropping (i.e. cereals and legume) & 4 \\
\hline Crop diversity & A variety of crops & 72 \\
\hline \multicolumn{3}{|l|}{ Information related } \\
\hline $\begin{array}{l}\text { Joined information } \\
\text { group }\end{array}$ & Joined information sharing group (i.e. on livestock diseases, new technologies) & 77 \\
\hline
\end{tabular}

The percentages need not add up to $100 \%$ since some households had adopted more than one adaptation practice 


\section{Data analysis}

\section{Set-up of the analysis}

First, we examined correlations among household socioeconomic variables and excluded variables with correlation coefficients greater than 0.4 and computed the adaptive capacity (AC) (Fig. 1). Second, we tested for the association between the AC and adoption using number of adopted practices (Fig. 1), and AC and three dimensions of local institutions (Fig. 1). Next, we explored the effects of the three dimensions of local institutions and AC on number of adaptation options adopted (Fig. 1). Finally, we examined the effects of institutions and household socio-economic characteristics, the five capitals and the spatial variables on the adoption of the total number of adaptation options (Fig. 1). A normality test showed that the distributions of the AC, the number of adopted adaptation options, the spatial variables and the three dimensions of local institutions were not significantly different from a normal distribution (results not presented).

\section{Computing AC}

Literature on determinants of $\mathrm{AC}$ refers to entitlement and command over resources and shows a positive relationship between access to natural, physical, human, financial and social capital and capacity to adapt (Dulal et al. 2010; Eakin and Bojorquez-Tapia 2008; Tompkins and Adger 2004). Thus, households' characteristics (i.e. skills and education) and access to resources are common

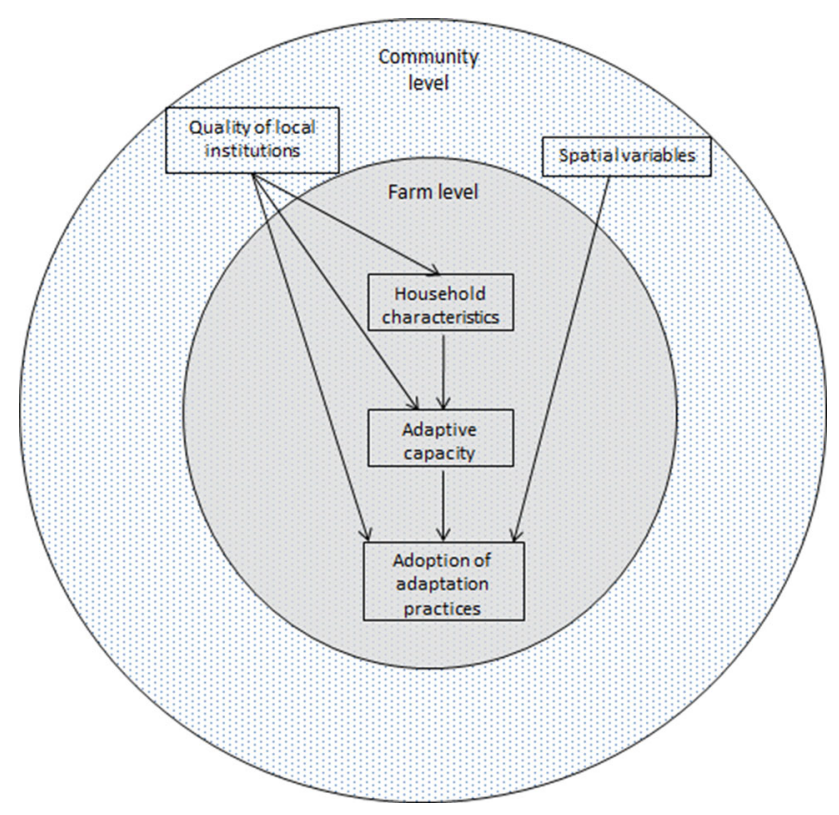

Fig. 1 A conceptual illustration of the set-up of the analysis determinants used in adaption studies. Households with few resources and/or poor access to them seem to have less capacity to adapt to climate change and are more exposed to its negative impacts (Smit and Wandel 2006). Following this empirical evidence, the socio-economic characteristics were normalized by converting them into indices using Eq. 2.

$\left(x_{j}=\frac{S_{i}-S_{\min }}{S_{\max }-S_{\min }}\right)$

where $x_{j}=$ index for each of household variable $j, S_{j}=$ original value for each variable for household $j$, and $S_{\min }$ and $S_{\max }=$ minimum and maximum values for each variable $j=1,2, \ldots, 400$

Subsequently, the indices for the various characteristics were aggregated into their respective capital $(Z)$ type for each household following the framework outlined by Yohe and Tol (2002) (Eq. 3). The framework of Yohe and Tol (2002) provides a simple but functional representation of adaptive capacity. The five types of capital were assumed to be equally important in their contribution to the overall AC. Thus, we computed the AC by summing up the five capitals $(Z$ ) (Eq. 3) and then dividing by five (the total number of capitals) (Eq. 4). This approach to the five capitals was tested by comparing the AC values computed with the number of adopted agricultural practices.

$Z_{k j}=\left(\sum_{i=1}^{n} x_{i}\right) / n$

$\mathrm{AC}_{j}=\left(\sum_{i=1}^{k} Z_{i}\right) / 5$

where $\quad \mathrm{AC}_{j}=$ adaptive capacity for household $j$, $n=$ number of variables constituting each of the five capitals for household $j, k=1, \ldots, 5$ (i.e. five types of capital for household $j$ ). But before calculating AC, we tested for normality of our data.

We acknowledge the potential drawback of using equal weight for all capitals. In the absence of field data to indicate preferential weights, we conducted a sensitivity analysis by taking five steps between zero and one for each of the five capitals. Then, we computed three adaptive capacities indices using a random combination of weights for the five capitals. Finally, we performed a pairwise correlation to see how sensitive the new adaptive capacity (AC) indices were to the different weights when assigned randomly to each capital. The results showed that the correlation coefficient of the three new AC indices ranged between $\rho=0.577$ and $\rho=0.9615$ and were significantly correlated (at $\rho<0.001$ ) to our original AC index. These high correlation coefficients suggest that our AC is not very sensitive to differential weights. 


\section{Association between AC, adoption and local institutions}

We used ordinary least squares (OLS) regression to test whether the number of adopted practices was related to $\mathrm{AC}$ (Eq. 5). Next, we analysed the association between $\mathrm{AC}$ and local institutions variables using Eq. 6.

$\mathrm{AC}_{j}=\delta_{1}+\delta_{2} S_{j}+\varepsilon_{j}$

$\mathrm{AC}_{j}=\beta_{1}+\beta_{2} \mathrm{TS}_{j}+\beta_{3} \mathrm{RoL}_{j}+\beta_{4} \mathrm{GA}_{j}+\varepsilon_{j}$

where $\mathrm{AC}_{j}=$ adaptive capacity for household $j, S_{j}=$ number of adopted adaptation options by household $j$, $\mathrm{TS}_{j}=$ tenure security, $\mathrm{RoL}_{j}=$ rule of law, $\mathrm{GA}_{j}=$ governance and accountability for household $j$, and $\varepsilon_{j}=$ random error term.

If $\mathrm{AC}$, number of adopted practices and the three dimensions of local institutions are positively related, then we expect $\delta_{2}, \beta_{2}, \beta_{3}$ and $\beta_{4}$ to be significantly larger than zero. We thereby test the hypothesis that good institutions are likely to facilitate coordination and cooperation reducing social conflicts among households in a community (Bellows and Miguel 2009; Toulmin 2009) and consequently promote private investments, thereby increasing household adaptive capacity. If in contrast, good institutions reduce the incentive for investments due to free riding for example, the coefficients will be negative.

\section{Institutions and adoption of adaptation practices}

We explored the association between adoption of adaptation practices and the three dimensions of institutions in two steps. First, and for robustness, we use (1) number of adopted practices (Eq. 7) and (2) adoption as a binary variable (Eq. 8) as the dependent variable.

$S_{j}=\beta_{0}+\beta_{1} \mathrm{TS}_{j}+\beta_{2} \mathrm{RoL}_{j}+\beta_{3} \mathrm{GA}_{j}+\varepsilon_{j}$

where $\mathrm{S}_{j} \mathrm{TS}_{j}, \mathrm{RoL}_{j}, \mathrm{GA}_{j}$ and $\varepsilon_{j}$ are as explained in Eqs. (5) and (6) above

Logit $\left(\mathrm{A}_{j}\right)=\beta_{0}+\beta_{1} \mathrm{TS}_{j}+\beta_{2} R o L_{j}+\beta_{3} \mathrm{GA}_{j}+\varepsilon_{j}$

where $A=$ adoption of practices as a binary (i.e. $\mathrm{Y} / \mathrm{N}$ ). ${ }^{4}$

In order to estimate the explanatory power of $\mathrm{AC}$ on adoption of adaptation practices, we repeated regressions as defined in Eqs. 7 and 8, but included AC as an explanatory variable. Finally, we explored the relationship between adopted adaptation practices and household socioeconomic variables, the five capitals and spatial variables by these factors as control in Eq. 8 .

\footnotetext{
4 That is household who had adopted any of the adaptation practice was assigned dummy variable 1 and 0 otherwise.
}

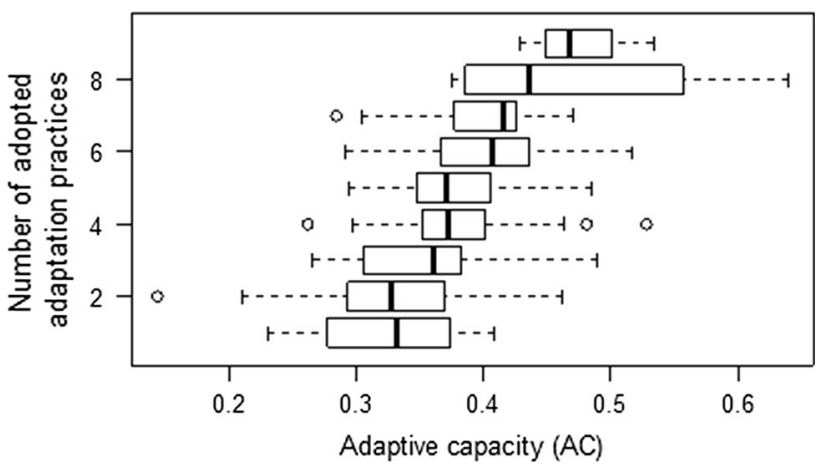

Fig. 2 The association between number of adopted adaptation practices and adaptive capacity (adjusted $r^{2}=0.22, p<0.001$, adaptive capacity is joint score of the different capitals)

\section{Results}

\section{Adaptive capacity, adoption and local institutions}

There was a positive and significant $(p<0.001)$ association between the number of adopted practices and $\mathrm{AC}$ (Fig. 2). AC explained about $22 \%$ of the total variation in the number of adopted practices. Also in the OLS regression, $\mathrm{AC}$ and the number of adopted practices were positive and significantly $(p<0.001)$ associated. ${ }^{5}$ AC was positively related to the three dimensions of local institutions: tenure security, rule of law and governance and accountability (Table 2).

The combined model with all three dimensions of local institutions also had a positive and significant $(p<0.001)$ association with $\mathrm{AC}$ with each of the dimensions, adding significantly to overall model performance, implying that the effects of the three dimensions of local institutions on $\mathrm{AC}$ are complementary.

\section{Effects of institutions on adoption}

Tenure security and governance and accountability were positively related to the number of adopted practices (Table A4). AC and high quality of tenure security and governance and accountability had a positive and significant association with the number of adopted practices, suggesting that the effects of the three variables on adoption are complementary and that besides AC, other variables determine adoption.

\footnotetext{
5 We performed a logit regression between the $\mathrm{AC}$ and the adoption of adaptation practices (as a binary response) for robustness. There was a positive and significant $(p<0.001)$ association between AC and adoption of adaptation practices (results not shown).
} 
Table 2 Slope and proportion of explained variance showing the relationship between the three dimensions of institutions (tenure security, rule of law and 'governance and accountability') in explaining adaptive capacity (AC)

\begin{tabular}{lllll}
\hline Dimension of local institutions & $\begin{array}{l}\mathrm{AC} \\
(1)\end{array}$ & $\begin{array}{l}\mathrm{AC} \\
(2)\end{array}$ & $\begin{array}{l}\mathrm{AC} \\
(3)\end{array}$ & $\begin{array}{l}\mathrm{AC} \\
(4)\end{array}$ \\
\hline Tenure security & $\begin{array}{l}0.087^{* * *} \\
(3.94)\end{array}$ & & & $0.088^{* * *}$ \\
& & $0.009^{* * *}$ & & $\begin{array}{l}(4.49) \\
0.0123^{* * *}\end{array}$ \\
Rule of law & & $(2.17)$ & & $(1.98)$ \\
& & & $0.015^{* * *}$ & $0.077^{* * *}$ \\
Governance and accountability & & & $(2.38)$ & $(4.21)$ \\
& & $0.262^{* * *}$ & $0.381^{* * *}$ & $0.237^{* * *}$ \\
Constant & $0.341^{* * *}$ & $(20.11)$ & $(70.02)$ & $(15.80)$ \\
$R^{2}$ & $(49.13)$ & 0.02 & 0.02 & 0.09 \\
$N$ & 0.05 & 400 & 400 & 400 \\
\hline
\end{tabular}

$N$ stands for sample size (apply to all tables). Between parentheses, the absolute value of $t$ statistic clustered by village is given. $* * *$ and $* * *$ indicate significance at 10,5 and at $1 \%$, respectively (applies to all Tables). To increase rigour in our data analysis, we perform four independent OLS regressions. First, we perform three independent OLS regression associating AC with the three dimensions of local institutions separately (i.e. columns 1-3) and, secondly associated AC with the three local institutions together (column 4). A blank cell in any of the columns indicates that the respective variables were excluded in the regression (applies to all tables)

\section{Effects of household socio-economic characteristics and institutions on adoption}

High crop income, financial savings, natural resource constraints, years lived in the village and membership in community groups were positively related to crop-related adaptation practices (Table 3). Crop income and years lived in the village were positively related to crop-related adaptation practices ('use of hybrid seeds', 'use of manure as fertilizer', 'erosion control', 'more cropping plots' and 'crop diversity'). Membership to community groups was positively related to crop-related adaptation practices intensification (hybrid seeds, erosion control and intercropping). High financial saving and natural resource constraints were positively related to the 'use of hybrid seeds' and the 'use of manure as fertilizer'. However, the increase in the age of the household head, household dependency ratio and participation in group activities were negatively related to adoption of crop-related adaptation practices.

The age of the household head, access to credit, livestock wealth and membership to community groups were positively associated with income diversification practices ('start trade' and 'off-farm income'). Access to credit and gender of the households were positively related to the likelihood of taking 'off-farm jobs', while livestock wealth and 'membership to community groups' were positively associated with 'start trade'.

Livestock wealth, membership to community groups, household dependency ratio and financial saving had a positive and significant effect on adoption of livestockrelated adaptation practices (adoption of drought-tolerant animals, feed conservation and migration). Participation in community meetings and activities, access to credit and high 'natural resource constraints' were negatively associated with 'use of hired labour'.

Tenure security was positively related to feed conservation, but was negatively related to income diversification (i.e. 'off-farm jobs'). Governance and accountability and rule of law were positively related to more livestock-related adaptation practices supporting migration and 'use of hired labour', but were negatively related to crop intensification ('erosion control' and 'the use of hybrid seeds').

\section{Effects of capitals on adoption}

There was a positive and significant relationship between human capital and migration and use of hired labour (Table A5). Natural capital had a positive relationship with adoption of crop intensification practices. More financial capital was positively related to adoption of livestock-related adaptation practices ('drought-tolerant animals' and migration), income diversification practices and crop-related adaptation practices ('crop diversity', 'use of hybrid seeds' and 'more crop plots'), but less adoption of intercropping. More physical capital led to more crop and livestock-related adaptation practices and income diversification. Higher social capital led to more adoption of livestock-related practices.

\section{Effects of infrastructure on adoption of practices}

Distance to the tarmac road was positively associated with an increased 'use of manure', 'more crop plots', 'use of 


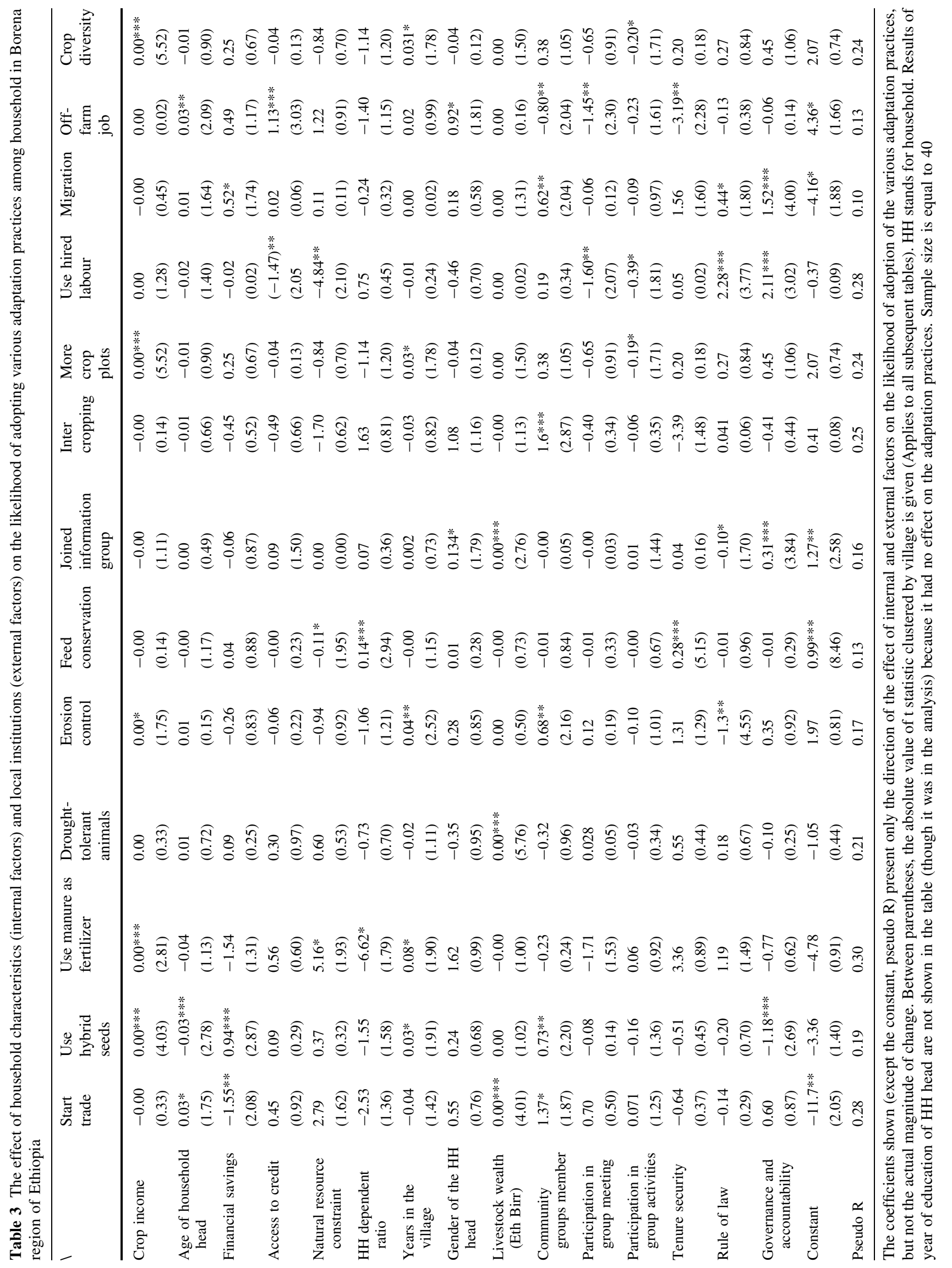


hired labour' and 'crop diversity' (Table A6). There was a negative effect of the distance to the tarmac road on the adoption of 'feed conservation'. An increase in the distance to the local markets was positively associated with adoption of 'drought-resistant animals'. An increase in the distance to the local market was negatively associated with the 'use of hybrid seeds', 'erosion control', 'use of hired labour', 'off-farm jobs' and 'crop diversity' implying that as distance to the local market increases, the adoption of crop intensification and income diversification practices declined.

There was no difference in adopted practices between male ( $75 \%$ of the sample)- and female (25\% of the sample)-headed households (Fig. A1). Nevertheless, the proportion of households adopting specific practices varied among the low-, medium- and high-income households (Fig. A2). About $50 \%$ of the high-, medium- and lowincome households had adopted seven, five and three practices, respectively. Moreover, the results suggest that local institutions have a larger impact on adoption of adaptation practices among male-headed households who join information groups and engage in income diversification (Table 3 ).

\section{Discussion}

We explored relationships between adaptive capacity (AC), the quality of local institutions (tenure security, rule of law and governance and accountability) and the number of adaptation practices adopted by agro-pastoral households. Aggregating household-level information into the AC indicator led to a loss of information (Table A9): the explanatory power of the statistical models using household-level information directly was stronger, both for the total number of adopted practices, as for the adoption of individual practices (Table A7). The loss of information when using either characteristics of household or local institutions suggests that better local institutions lead to changes in key household-level characteristics (e.g. membership to community groups, years lived in a village, access to credit, financial savings and crop income), which positively affect adopted adaptation strategies. This finding suggests that policies that enhance the quality of local institutions have the potential to support households to adapt by enhancing their AC in the short term and to adapt in the longer term by stimulating change in the household themselves, which then increases AC. These findings also partly confirm our hypothesis that the quality of local institutions is positively related to adaptation at household level, but it is difficult to say whether they are more important than characteristics of the household themselves. The amount of variability in total number of adopted adaptation practices explained by the household-level characteristics was larger than the amount of variation explained by the local institutions. However, some household characteristics were correlated with quality of the local institutions, thereby making it difficult to infer their relative importance. For individual practices, household characteristics were the most important factors, sometimes complemented, depending on the specific adaptation option, by the quality of local institutions and/or spatial variables (Table 3 and Table A6). Thus, policies aimed at supporting the management of local institutions have the potential of stimulating their quality and consequently management of rangeland resources, thereby fostering adaptation. In addition, provision of financial resources for strengthening local institutions may foster internal and external coordination and connections (i.e. feedback loops) that can ensure equity, transparency and the ability to seize adaptation opportunities.

Models using the five capitals as explanatory variables had less explanatory power than those using household characteristics directly (Table A5). So while AC and the five capitals provide an abstract way of representing the potential of a household to adapt (Adger and Vincent 2005; Dulal et al. 2010; Eakin and Bojorquez-Tapia 2008; Tompkins and Adger 2004) and can be used to compare systems (cf. Deressa et al. 2009), for site-specific studies they are perhaps not the best way of analysing the adoption behaviour of households. This is because using the five capitals typically masks the roles of specific household's characteristics and their functions in supporting adaptive capacity. Our analyses support earlier research that showed positive relationships between access to natural, physical, human, financial and social capital and the capacity to adapt (Adger 1996; Brooks and Adger 2004; Brouwer et al. 2007; Reid et al. 2007). However, other studies suggest that cognitive factors (i.e. risk perception, information management and behaviour) play a critical role (i.e. helping household to make decision on resource use and management) in determining household-level AC (Grothmann and Patt 2005; Peacock et al. 2005). The advantage of using the five capitals is the increased transparency as a measure of AC. The drawback of using cognitive factors is that farmers with a high-risk perception are likely to adopt measures simply because of their perception, not necessarily because they have intrinsically a high AC (Clayton 2012). So, if the likelihood of adoption is then used as an indicator of $\mathrm{AC}$, the whole analyses will have difficulty to distinguish the driver of the process: Was it the chicken (perception) or was it the egg (AC)? We therefore believe it is more appropriate to use an $\mathrm{AC}$ indicator based on intrinsic farm household characteristics, supplemented by information on local institutions. The five-capital approach then serves as a useful reference that covers several key 
aspects that characterize households and thereby allows standardization for across site comparisons. This approach to gaining insight in AC of households across socio-economic and agro-ecological gradients uses a bottom-up approach based on primary data collection at households level, rather than a top-down approach or from anecdotal information about case studies or expert opinion (Adger and Vincent 2005; Gupta et al. 2010; Jones et al. 2010). We see as an important step in adaptation research-because it helps to unmask the roles of the specific household characteristics and their functions as well as local institutions in supporting household adaptive capacity.

\section{The role of $\mathrm{AC}$ and the three dimensions of local institutions on adaptation}

The positive and complementary effect of the three dimensions of local institutions on AC shows that higherquality local institutions affect household-level welfare positively, especially through accumulation of assets and other resources that are important determinants of AC (cf. Grootaert and Narayan 2004; Little et al. 2001). The positive relationship between tenure security and governance and accountability and the number and the type of adaptation practices adopted suggests that high-quality local institutions increase the ability of households to intensify crop and livestock production. For instance, to reduce the negative impact of drought on livestock wealth, high quality of governance and accountability ensures that enclosures (areas reserved for grazing by calves and cows) are not grazed during non-dry season by imposing strict penalties to errant households, thereby increasing the ability of households to adapt (Chavas et al. 2005; KabuboMariara 2007).

\section{Effects of household socio-economic characteristics on adoption of adaptation practices}

\section{Crop-related adaptation practices}

Whether larger crop income is a cause or an effect of adoption of crop-related adaptation practices is difficult to determine, although previous research has shown that when land is limited, farmers are motivated to intensify crop production (Baidu-Forson 1999; Deressa et al. 2009; Di Falco et al. 2011). The numbers of years spent in a village is often a good indicator of the willingness of farmers to invest in improving soil fertility and intensifying crop productivity, as well as a representation of experience gained that enable households to adapt (Deressa et al. 2009; Notenbaert et al. 2012; Odendo et al. 2010). Other factors related to adoption of crop-related adaptation practices include membership to community groups, which may enhance adoption of crop-related adaptation practices by facilitating sharing of knowledge and ideas (Bryan et al. 2013). On the other hand, natural resource constraints hinder households ability to secure food (cf. Marenya and Barrett 2007; Mazzucato et al. 2001; Shiferaw et al. 2009) and the ability to save money to acquire inputs (Di Falco et al. 2011).

\section{Income diversification}

Older farmers, owing to their accumulated experience and wealth, can diversify their income to safeguard their livelihood (Table 3) (Aklilu and Catley 2011; Bayard et al. 2007). The positive relationship between access to credit and income diversification shows the role institutions may play in enabling adaptation (Di Falco et al. 2011). Maleheaded households engage more easily in income diversification than female-headed households, highlighting the need for effective interventions to improve the AC of women (Njuki and Sanginga 2013; Notenbaert et al. 2012). The strong relationship between livestock wealth and income diversification can be explained by a 'banking' effect: selling livestock (products) can provide capital to, for example, 'start trade' (Ouma et al. 2011), as a diversification strategy (cf. Carter and Barrett 2006; Little et al. 2001). Thus, a policy to support investment in institutions (such as the banks) may stimulate households to save and access credit and enhance their ability to adapt. The negative relationship between group membership and participation in group activities and income diversification may be explained by the time spent in group meetings and activities which reduces the time required to pursue other activities (Marenya and Barrett 2007). This suggests that policies aimed at encouraging informal social networks (financially or materially) may facilitate the flow of information and coordination of activities much more efficiently, thereby boosting household AC. High tenure security showed a negative relationship with the adoption of income diversification options.

\section{Livestock-related adaptation practices}

Livestock wealth is a good indicator of the capacity of households to intensify livestock production (cf. Amsalu and De Graaff 2007; Bekele and Drake 2003; Di Falco et al. 2011; Marenya and Barrett 2007). Financial savings enhance households' capacity to adopt livestock-related adaptation practices, for example, by enabling them to buy food (or other social amenities) when migrating or looking for pastures (Barrett et al. 2006). A high household dependency ratio would suggest households' willingness to secure more milk and income through livestock-related adaptation practices given the greater family needs (cf. 
Somda et al. 2005), while membership to community groups enhances livestock-related adaptation practices in semi-arid areas as a source of information on water and pasture availability (cf. Deressa et al. 2009; Di Falco et al. 2011). High-quality tenure security enhances adoption of livestock-related adaptation practices by enabling households to make long-term production decisions (Deininger and Jin 2006; Kabubo-Mariara 2007), while high-quality local institutions that stimulate the choice for enclosures are a source of livestock feed during dry periods.

\section{Effects of infrastructure on adoption of adaptation practices}

Poor access to a tarmac road was positively related to the adoption of income diversification and crop intensification practices, but negatively related to livestock-related adaptation practices. This could be explained by the fact that crop production in the region is mostly for home consumption (Angassa and Oba 2008). Lack of access to a tarmac road (and therefore to markets) means that to feed the family the farmers need to intensify and diversify food production to obtain a reasonable harvest. In contrast, livestock is the key cash generator for these agro-pastoral households, and lack of access to a tarmac road means that marketing of livestock products is more difficult and therefore a disincentive to intensify livestock production. Our findings suggest that besides household-level characteristics, their geographical location needs to be taken into account to explain adoption of agricultural practices that can reduce vulnerability to climate variability.

\section{Conclusions}

Aggregating household-level information into the $\mathrm{AC}$ indicator or the five capitals for explaining adoption behaviour leads to loss of information. So while AC and the five capitals can be used as an abstract way representing the potentials of a household to adapt and can easily be compared across systems, for site-specific studies they are not the best way of analysing the adoption behaviour of households. We conclude that the best way of analysing behaviour of households for site-specific study is to use household-level information directly. Our results suggest that better local institutions lead to changes in key household-level characteristics, which positively affect adoption. Thus, policies aimed at supporting the management and strengthening of local institutions can foster adaptation to an increasingly erratic climate.

Acknowledgments This work was carried out as part of the Consultative Group on International Agricultural Research Program on
Climate Change, Agriculture and Food Security (CCAFS). The authors thank Dr. Solomon Desta whose insights played a pivotal role in structuring the data collection in Borena, Ethiopia.

Open Access This article is distributed under the terms of the Creative Commons Attribution 4.0 International License (http://crea tivecommons.org/licenses/by/4.0/), which permits unrestricted use, distribution, and reproduction in any medium, provided you give appropriate credit to the original author(s) and the source, provide a link to the Creative Commons license, and indicate if changes were made.

\section{References}

Abule E, Snyman HA, Smit GN (2005) Comparisons of pastoralists perceptions about rangeland resource utilisation in the Middle Awash Valley of Ethiopia. J Environ Manag 75(1):21-35. doi:10.1016/j.jenvman.2004.11.003

Acemoglu D, Johnson S (2005) Unbundling institutions. J Polit Econ 113:949-995. doi:10.3386/w9934

Adger WN (1996) Approaches to vulnerability to climate change. CSERGE working paper GEC 96-05. Centre for social and economic research on the global environment, University of East Anglia, Norwich, and University College London

Adger WN (2003) Social capital, collective action and adaptation to climate change. Econ Geogr 79(4):387-404. doi:10.1111/j.19448287.2003.tb00220.x

Adger WN (2006) Vulnerability. Glob Environ Change 16(3):268-281. doi:10.1016/j.gloenvcha.2006.02.006

Adger WN, Vincent K (2005) Uncertainty in adaptive capacity. C R Geosci 337(4):399-410. doi:10.1016/j.crte.2004.11.004

Aklilu Y, Catley A (2011) Shifting sand: the commercialization of camels in mid-altitude Ethiopia and beyond. Feinstein International Center, Tufts University, Medford

Amsalu A, De Graaff J (2007) Determinants of adoption and continued use of stone terraces for soil and water conservation in an Ethiopian highland watershed. Ecol Econ 61(2):294-302. doi:10.1016/j.ecolecon.2006.01.014

Angassa A, Oba G (2008) Herder perceptions on impacts of range enclosures, crop farming, fire ban and bush encroachment on the rangelands of Borana, Southern Ethiopia. Hum Ecol 36(2):201-215. doi:10.1007/s10745-007-9156-Z

Babulo B, Muys B, Nega F, Tollens E, Nyssen J, Deckers J, Mathijs E (2009) The economic contribution of forest resource use to rural livelihoods in Tigray, Northern Ethiopia. For Policy Econ 11(2):109-117. doi:10.1016/j.forpol.2008.10.007

Baidu-Forson J (1999) Factors influencing adoption of land-enhancing technology in the Sahel: lessons from a case study in Niger. Agric Econ 20(3):231-239. doi:10.1016/S0169-5150(99)00009-2

Barrett CB, Marenya PP, McPeak J, Minten B, Murithi F, Oluoch-Kosura W, Place F, Randrianarisoa JC, Rasambainarivo J, Wangila J (2006) Welfare dynamics in rural Kenya and Madagascar. J Dev Stud 42(2):248-277. doi:10.1080/00220380500405394

Bayard B, Jolly CM, Shannon DA (2007) The economics of adoption and management of alley cropping in Haiti. J Environ Manag 84(1):62-70. doi:10.1016/j.jenvman.2006.05.001

Bekele W, Drake L (2003) Soil and water conservation decision behavior of subsistence farmers in the Eastern highlands of Ethiopia: a case study of the Hunde-Lafto area. Ecol Econ 46(3):437-451. doi:10.1016/S0921-8009(03)00166-6

Bellows J, Miguel E (2009) War and local collective action in Sierra Leone. J Public Econ 93(12):1144-1157. doi:10.1016/j.jpubeco. 2009.07.012 
Below T, Artner A, Siebert R, Sieber S (2010) Micro-level practices to adapt to climate change for African small-scale farmers. IFPRI discussion paper No. 953. International Food Policy Reseach Institute. Washington

Bill and Melinda Gates Foundation (2010) Agricultural development outcome indicators: initiative and sub-initiative progress indicators and pyramid of outcome indicators, BMGF. https://docs. gatesfoundation.org/Documents/guide-to-actionable-measure ment.pdf. Accessed 10 Apr 2014

Binswanger HP, McIntire J (1987) Behavioral and material determinants of production relations in land-abundant tropical agriculture. Econ Dev Cult Change 36(1):73-99. doi:10.1086/451637

Bowles S, Gintis H (2002) Social capital and community governance. Econ J 112(483):F419-F436. doi:10.1111/1468-0297.00077

Brooks N, Adger WN (2004) Assessing and enhancing adaptive capacity. In: Lim B (ed) Adaptation policy framework. United Nation Development Programme, New York, pp 165-181

Brouwer R, Akter S, Brander L, Haque E (2007) Socioeconomic vulnerability and adaptation to environmental risk: a case study of climate change and flooding in Bangladesh. Risk Anal 27(2):313-326. doi:10.1111/j.1539-6924.2007.00884.x

Bryan E, Ringler C, Okoba B, Roncoli C, Silvestri S, Herrero M (2013) Adapting agriculture to climate change in Kenya: household strategies and determinants. J Environ Manag 114:26-35. doi:10.1016/j.jenvman.2012.10.036

Carter M, Barrett C (2006) The economics of poverty traps and persistent poverty: an asset-based approach. J Dev Stud 42(2):178-199. doi:10.1080/00220380500405261

Chavas J-P, Petrie R, Roth M (2005) Farm household production efficiency: evidence from the Gambia. Am J Agric Econ 87(1):160-179. doi:10.1111/j.0002-9092.2005.00709.x

Clayton SD (2012) The Oxford handbook of environmental and conservation psychology. Oxford University Press, Oxford

Cooper PJM, Dimes J, Rao KPC, Shapiro B, Shiferaw B, Twomlow S (2008) Coping better with current climatic variability in the rainfed farming systems of sub-Saharan Africa: an essential first step in adapting to future climate change? Agric Ecosyst Environ 126(1):24-35. doi:10.1016/j.agee.2008.01.007

Coppock DL (1994) The borana plateau of southern Ethiopia: synthesis of pastoral research, development and change, 1980-91. ILCA, Addis Ababa, Ethiopia

Croppenstedt A, Demeke M, Meschi MM (2003) Technology adoption in the presence of constraints: the case of fertilizer demand in Ethiopia. Rev Dev Econ 7(1):58-70. doi:10.1111/ 1467-9361.00175

Debela N, Mohammed C, Bridle K, Corkrey R, McNeil D (2015) Perception of climate change and its impact by smallholders in pastoral/agropastoral systems of Borana, South Ethiopia. SpringerPlus 4:236. doi:10.1186/s40064-015-1012-9

Deininger K, Jin S (2006) Tenure security and land-related investment: evidence from Ethiopia. Eur Econ Rev 50(5):1245-1277. doi:10.1016/j.euroecorev.2005.02.001

Dercon S (2006) Vulnerability: a micro perspective. Working paper 149. Oxford University, Queen Elizabeth House (QEH)

Deressa TT, Hassan RM, Ringler C, Alemu T, Yesuf M (2009) Determinants of farmers' choice of adaptation methods to climate change in the Nile Basin of Ethiopia. Glob Environ Change 19(2):248-255. doi:10.1016/j.gloenvcha.2009.01.002

Di Falco S, Veronesi M, Yesuf M (2011) Does adaptation to climate change provide food security? A micro-perspective from Ethiopia. Am J Agric Econ 93(3):829-846. doi:10.1093/ajae/aar006

Dulal H, Brodnig G, Onoriose CG, Thakur HK (2010) Capitalising on assets: vulnerability and adaptation to climate change in Nepal. The World Bank social development papers No 121. The World Bank, Washington
Eakin H, Bojorquez-Tapia L (2008) Insights into the composition of household vulnerability from multicriteria decision analysis. Glob Environ Change 18(1):112-127. doi:10.1016/j.gloenvcha. 2007.09.001

Fafchamps M, Minten B (2001) Social capital and agricultural trade. Am J Agric Econ 83(3):680-685. doi:10.1111/0002-9092.00190

Field CB, Barros V, Stocker TF, Dahe Q, Dokken DJ, Plattner G-K, Ebi KL, Allen SK, Mastrandrea MD, Tignor M, Mach KJ, Midgley PM (2012) Managing the risks of extreme events and disasters to advance climate change adaptation. A special report of working groups I and II of the intergovernmental panel on climate change. Cambridge University Press, Cambridge and New York, p 582

Fratkin E (1991) Surviving drought and development: ariaal pastoralists of Northern Kenya. Am Ethnol 21(4):974-975. doi:10. 1525/ae.1994.21.4.02a00880

Grootaert C, Narayan D (2004) Local institutions, poverty and household welfare in Bolivia. World Dev 32(7):1179-1198. doi:10.1016/j.worlddev.2004.02.001

Grothmann T, Patt A (2005) Adaptive capacity and human cognition: the process of individual adaptation to climate change. Glob Environ Change 15(3):199-213. doi:10.1016/j.gloenvcha.2005. 01.002

Gupta J, Termeer C, Klostermann J, Meijerink S, van den Brink M, Jong P, Nooteboom S, Bergsma E (2010) The adaptive capacity wheel: a method to assess the inherent characteristics of institutions to enable the adaptive capacity of society. Environ Sci Policy 13(6):459-471. doi:10.1016/j.envsci.2010.05.006

Hisali E, Birungi P, Buyinza F (2011) Adaptation to climate change in Uganda: evidence from micro level data. Glob Environ Change 21(4):1245-1261. doi:10.1016/j.gloenvcha.2011.07.005

Hulme M, Doherty RM, Ngara T, New MG, Lister D (2001) African climate change: 1900-2100. Clim Res 17(2):145-168. doi:10. 3354/cr017145

Intergovernmental Panel on Climate Change (IPCC) (2013) Climate change 2013: The physical science basis. Contribution of working group I to the fifth assessment report of the intergovernmental panel on climate change [Stocker, T. F., Qin, D., Plattner, G-K., Tignor, M., Allen, S. K., Boschung, J., Nauels, A., Xia, Y., Bex, V., Midgley, P. M., (ed)]. Cambridge University Press, Cambridge, United Kingdom and New York, NY, USA, p 1535. doi:10.1017/CBO9781107415324

Jones PG, Thornton PK (2009) Croppers to livestock keepers: livelihood transitions to 2050 in Africa due to climate change. Environ Sci Policy 12(4):427-437. doi:10.1016/j.envsci.2008. 08.006

Jones L, Ludi E, Levine S (2010) Towards a characterisation of adaptive capacity: a framework for analysing adaptive capacity at the local level. Overseas Development Institute

Kabubo-Mariara $\mathbf{J}$ (2007) Land conservation and tenure security in Kenya: Boserup's hypothesis revisited. Ecol Econ 64(1):25-35. doi:10.1016/j.ecolecon.2007.06.007

Kelly P, Adger W (2000) Theory and practice in assessing vulnerability to climate change and facilitating adaptation. Clim Change 47(4):325-352. doi:10.1023/A:1005627828199

Kurukulasuriya P, Mendelsohn R, Hassan R, Benhin J, Deressa T, Diop M, Eid HM, Fosu KY, Gbetibouo G, Jain S (2006) Will African agriculture survive climate change? World Bank Econ Rev 20(3):367-388. doi:10.1093/wber/lh1004

Little PD, Smith K, Cellarius BA, Coppock DL, Barrett JC (2001) Avoiding disaster: diversification and risk management among East African herders. Dev Change 32(3):401-433. doi:10.1111/ 1467-7660.00211

Marenya PP, Barrett CB (2007) Household-level determinants of adoption of improved natural resources management practices 
among smallholder farmers in Western Kenya. Food Policy 32(4):515-536. doi:10.1016/j.foodpol.2006.10.002

Martin M (1985) Design of a food intake study in two Bambara villages in the Segou region of Mali with preliminary findings. In: Hill A (ed) Population, Health and Nutrition in the Sahel. Routledge and Kegan Paul, London, pp 289-317

Mazzucato V, Niemeijer D, Stroosnijder L, Rolling N (2001) Social networks and the dynamics of soil water conservation in Sahel. Gatekeeper series SA 101. International Institute for Environment and Development, London. http://hdl.handle.net/11245/1. 425485

Nawrotzki RJ, Hunter LM, Dickinson TW (2012) Natural resources and rural livelihoods: differences between migrant and nonmigrants in Madagascar. Demogr Res 26(24):661-700. doi:10. 4054/DemRes.26.24

Nhemachena C, Hassan R (2007) Micro-level analysis of farmers' adaption to climate change in Southern Africa. IFPRI discussion paper No 00714. International Food Policy Research Institute, Washington

Njuki J, Sanginga PC (2013) Women, livestock ownership and markets: bridging the gender gap in eastern and southern Africa. Routledge, London and New York

Notenbaert A, Karanja SN, Herrero M, Felisberto M, Moyo S (2012) Derivation of a household-level vulnerability index for empirically testing measures of adaptive capacity and vulnerability. Reg Environ Change 13(2):459-470. doi:10.1007/s10113-0120368-4

Odendo M, Obare G, Salasya B (2010) Farmers' perceptions and knowledge of soil fertility degradation in two contrasting sites in western Kenya. Land Degrad Dev 21(6):557-564. doi:10.1002/ ldr.996

Ouma R, Mude A, van de Steeg J (2011) Dealing with climate-related risks: some pioneering ideas for enhanced pastoral risk management in Africa. Exp Agric 47(2):375-393. doi:10.1017/ S0014479710000888

Peacock WG, Brody SD, Highfield W (2005) Hurricane risk perceptions among Florida's single family homeowners. Landsc Urban Plan 73(2):120-135. doi:10.1016/j.landurbplan.2004.11. 004

Reid S, Smit B, Caldwell W, Belliveau S (2007) Vulnerability and adaptation to climate risks in Ontario agriculture. Mitig Adapt Strateg Glob Change 12(4):609-637. doi:10.1007/s11027-0069051-8

Rufino M, Thornton P, Ng'ang'a S, Ianetta M, Jones P, van Wijk M, Herrero M (2013) Transitions in agro-pastoralist systems of East Africa: impacts on food security and poverty. Agric Ecosyst Environ 179:215-230. doi:10.1016/j.agee.2013.08.019

Saenz R, Morales MC (2005) Demography of race and ethnicity. In: Poston DL, Micklin M (eds) Handbook of population. Kluwer Academic/Plenum, New York, pp 169-208. doi:10.1007/0-38723106-4_7

Scoones I (2009) Livelihoods perspectives and rural development. J Peasant Stud 36(1):171-196. doi:10.1080/03066150902820503
Shiferaw BA, Okello J, Reddy RV (2009) Adoption and adaptation of natural resource management innovations in smallholder agriculture: reflections on key lessons and best practices. Environ Dev Sustain 11(3):601-619. doi:10.1007/s10668-007-9132-1

Smit B, Pilifosova O (2001) Adaptation to climate change in the context of sustainable development and equity. In: IPCC climate change. Impacts, adaptations and vulnerability. CUP, Cambridge, UK, pp 879-906

Smit B, Wandel J (2006) Adaptation, adaptive capacity and vulnerability. Glob Environ Change 16(3):282-292. doi:10.1016/j. gloenvcha.2006.03.008

Solomon D, Coppock D (2004) Pastoralism under pressure: tracking system change in Southern Ethiopia. Hum Ecol 32(4):465-486. doi: $10.2307 / 4603531$

Solomon TB, Snyman HA, Smit GN (2007) Cattle-rangeland management practices and perceptions of pastoralists towards rangeland degradation in the Borana zone of southern Ethiopia. J Environ Manag 82(4):481-494. doi:10.1016/j.jenvman.2006. 01.008

Somda J, Kamuanga M, Tollens E (2005) Characteristics and economic viability of milk production in the smallholder farming systems in The Gambia. Agric Syst 85(1):42-58. doi:10.1016/j. agsy.2004.07.011

Tambo JA, Abdoulaye T (2012) Climate change and agricultural technology adoption: the case of drought tolerant maize in rural Nigeria. Mitig Adapt Strateg Glob Change 17(3):277-292. doi:10.1007/s11027-011-9325-7

Thornton PK, Boone RB, Galvin KA, Burnsilver SB, Waithaka MW, Kuyiah J, Karanja S, Gonzalez-Estrada E, Herrero M (2007) Coping strategies in livestock-dependent households in East and Southern Africa: a synthesis of four case studies. Hum Ecol 35:461-476. doi:10.1007/s10745-007-9118-5

Thornton PK, Jones PG, Alagarswamy G, Andresen J, Herrero M (2010) Adapting to climate change: agricultural system and household impacts in East Africa. Agric Syst 103(2):73-82. doi:10.1016/j.agsy.2009.09.003

Tompkins EL, Adger W (2004) Does adaptive management of natural resources enhance resilience to climate change?. Ecol Soc 9 (2):10. doi: Artn 10. http://www.ecologyandsociety.org/vol9/ iss $2 / \operatorname{art} 10$

Toulmin C (2009) Securing land and property rights in sub-Saharan Africa: the role of local institutions. Land Use Policy 26(1):10-19. doi:10.1016/j.landusepol.2008.07.006

Voors MJ, Bulte EH, Damania R (2011) Income shocks and corruption in Africa: does a virtuous cycle exist? J Afr Econ 20(3):395-418. doi:10.1093/jae/ejr011

Watson EE (2003) Examining the potential of indigenous institutions for development: a perspective from Borena. Dev Change 34(2):287-310. doi:10.1111/1467-7660.00306

Yohe G, Tol RSJ (2002) Indicators for social and economic coping capacity: moving toward a working definition of adaptive capacity. Glob Environ Change 12(1):25-40. doi:10.1016/ S0959-3780(01)00026-7 